\title{
A MULTIPROPRIEDADE IMOBILIÁRIA E O PRINCÍPIO NUMERUS CLAUSUS
}

\section{Fernando Medeiros Costa* Daniel Motta Gutierrez**}

Resumo: Estuda a multipropriedade imobiliária como Direito Real, é examinada a origem do conceito de propriedade e o surgimento da tutela constitucional da função social desta. Estuda-se o Projeto de Lei 7.553/2017 e avalia-se a necessidade da inserção do inciso XIV no artigo 1.225 do Código Civil Brasileiro. Conclui-se que a despeito do princípio numerus clausus do Código Civil Brasileiro, não há óbice a esta modalidade de propriedade no diploma legal, bem como a interpretação do referido artigo à luz da constituição apresenta viável o instituo da multipropriedade, sendo necessário, tão somente estabelecer a forma de exercício da multipropriedade imobiliária.

Palavras-chaves: Multipropriedade imobiliária. Direito imobiliário. Direito constitucional. Direito civil. Direito à propriedade.

\section{THE TIME SHARING SYSTEM AND THE NUMERUS CLAUSUS PRINCIPLE}

Abstract: The paper analyze the time-sharing system. Was examinated the origin of the concept of property and the emergence of constitutional protection of the Social Function of property. The draft Law 7.553 / 2017 is studied and the need to insert XIV in Article 1,225 of the Civil Code is assessed. As a methodology, the research was carried out in a bibliographical and qualitative case law. It is concluded that in spite of the numerus clausus principle there is no obstacle to the time-sharing, as well he interpretation of the law said article makes viable the institution of the time-sharing.

Keywords: Time share. Real state law. Constitutional rights. Civil rights. Property Law.

\section{INTRODUÇÃO}

Objetiva-se com este artigo rediscutir o princípio numerus clausus e avaliar a viabilidade da regulamentação da multipropriedade no ordenamento jurídico atual com base no Princípio da Função Social da Propriedade.

\footnotetext{
* Mestrando em Direito e Desenvolvimento pelo Centro Universitário Christus (UNICHRISTUS). Especialista em Direito do Consumidor (PAERPI). Pós-graduando em Direito Corporativo pela Faculdade Getúlio Vargas-RJ (FGV/RJ). Graduado em Direito pela Universidade de Fortaleza (UNIFOR). E-mail: fernando@medeirosadvocacia.com. ORCID: https://orcid.org/0000-0003-1517-8429

** Doutor e Mestre em Direito pela Pontifícia Universidade Católica de São Paulo. Professor da Graduação e Pós-Graduação do Centro Universitário Christus (UNICHRISTUS). Advogado. E-mail: dgutierrez@uol.com.br. ORCIRD: https://orcid.org/0000-0002-8314-1524
}

Revista Brasileira de Direito Civil em Perspectiva | e-ISSN: 2526-0243| Porto Alegre | v. 4 | n. 2

p. $120-135$ | Jul/Dez. 2018 
A evolução histórica do conceito de propriedade, demonstrou de forma claramente importância dada pelo legislador ao conceito e à proteção ao direito de propriedade. Com a diversificação das relações negociais e interpessoais, diversos novos direitos e modalidades de exercício de um direito existente foram criados e tutelados.

O legislador, ainda que atuasse de maneira proativa e com produção otimizada, dificilmente, teria como acompanhar em tempo real esta produção social e negocial. Assim, invariavelmente, uma série de direitos e deveres acabam ficando carentes de uma regulamentação específica.

A multipropriedade imobiliária, surgida para atender a uma demanda das pessoas em usar, gozar e dispor de um bem de maneira fracionada pelo tempo, é um exemplo desta modalidade de direito que surgiu da evolução negocial e ficou às margens de uma regulamentação específica em vários países por muito tempo.

Em diversas nações, a hoje denominada multipropriedade imobiliária, não foi inicialmente identificada como Direito Real à propriedade em si, tendo passeado pelos direitos obrigacionais e pelas sociedades para fins de exploração econômica até finalmente ser identificada, na maioria deles, como efetivo direito real de propriedade.

O objetivo deste ensaio é debater a possibilidade de se caracterizar a multipropriedade imobiliária como Direito Real previsto no artigo 1.225 do Código Civil, mediante a análise do princípio constitucional da Função Social da Propriedade.

Pretende-se investigar, em especial, a necessidade de inserção de inciso XIV, no art. 1.225 do Código Civil, com a previsão expressa da Multipropriedade Imobiliária para que esta seja tratada como Direito Real.

Serão, assim, analisados os elementos que caracterizam a multipropriedade imobiliária e que se tornam fundamentais para que seja esta encarada como Direito Real. Também é objetivo do ensaio fazer a análise do Projeto de Lei 7.553/2017 e as características trazidas consigo à modalidade de propriedade objeto do presente estudo, buscando-se propor, ao final, parâmetros e diretrizes para a regulamentação da multipropriedade imobiliária.

Inicialmente fez-se breve abordagem da noção embrionária do direito de propriedade e seu conceito desde os primeiros registros de seu aparecimento até os dias atuais. Realizou-se uma análise do conceito à luz da colonização brasileira e sua tutela por meio das constituições do Império e da República brasileiros.

Revista Brasileira de Direito Civil em Perspectiva | e-ISSN: 2526-0243| Porto Alegre | v. 4 | n. 2 | 
Em seguida, buscou-se apresentar a origem da multipropriedade imobiliária na Europa, seu surgimento na América, e em especial a demanda criada para esta modalidade de negócio no Brasil.

Analisou-se, por fim, a multipropriedade imobiliária à luz do Princípio da Função Social da Propriedade e o Projeto de Lei 7.553/2017.

O foco deste escrito é apresentar modelo e a técnica para a regulamentação da multipropriedade imobiliária com o escopo de dar maior segurança jurídica aos negócios que envolvem referido direito, os quais já são hoje amplamente realizados no $\mathrm{P}$ aís.

A pesquisa, de viés qualitativo e de cunho exploratório, será lastreada em levantamento bibliográfico e análise qualitativa jurisprudencial.

\section{O CONCEITO E A EVOLUÇÃO HISTÓRICA DA PROPRIEDADE}

Para a análise mais detida da multipropriedade, faz-se imprescindível proceder a uma breve análise da evolução do conceito de propriedade, desde os primeiros registros do seu surgimento até os dias atuais.

Os povos antigos fundamentaram o direito de propriedade em princípios distintos dos atualmente tutelados, ocasionado um regramento legal dissonante ao atual.

Os tártaros, povo étnico turcomano que ocupou orginalmente a hoje denominada República Autônoma da Crimeia, já identificavam uma relação de propriedade há muitos anos, entretanto, os mesmos consideravam a relação de propriedade com o seu rebanho, mas não faziam o mesmo com relação ao solo. Os antigos povos germânicos acreditavam que a terra não pertencia a ninguém, sendo possível de ser objeto de propriedade pelos indivíduos somente os frutos da terra.(COULANGES, 2006)

As mais remotas civilizações que habitaram a Grécia e a Itália, por outro lado, já há muito tinham a noção de propriedade privada da terra. Para os Romanos, a relação com a propriedade tinha características absolutas e de caráteres personalíssimos.

Na Declaração dos Direitos do Homem e do Cidadão, documento redigido em 1789, fruto da Revolução Francesa, passa-se a ter uma relação com a propriedade imobiliária mais próxima da atualidade brasileira. Neste diploma legal, a propriedade é tida como direito inviolável e sagrado. Ninguém dela podendo ser privado, a não ser quando a necessidade

Revista Brasileira de Direito Civil em Perspectiva | e-ISSN: 2526-0243| Porto Alegre | v. 4 | n. 2 |

p. $120-135$ | Jul/Dez. 2018 
pública legalmente comprovada o exigir e sob condição de justa e prévia indenização (COULANGES, 2006).

No Brasil, a primeira menção ao conceito de propriedade remonta à Constituição Política do Império, datada de 1824 que tutelava a "inviolabilidade dos Direitos Civis, e Políticos dos Cidadãos Brasileiros, que tem por base a liberdade, a segurança individual, e a propriedade, é garantida pela Constituição do Império, pela maneira seguinte" (BRASIL, 1824).

A Norma Constitucional de 1824 garantia ainda o Direito de Propriedade em toda a sua plenitude, trazendo consigo, provavelmente, em virtude das disputas de terra oriundas da divisão territorial nacional em províncias, a noção dos direitos atrelados à propriedade.

Excetuava-se, à utilização plena da propriedade, tão-somente, o interesse público, situação em que caberia a indenização ao cidadão pela desapropriação.

No mesmo sentido, foi a tutela da propriedade nas Constituições de 1824, 1891, 1934 e 1937, nos termos a seguir transcritos das respectivas constituições:

É garantido o Direito de Propriedade em toda a sua plenitude. Se o bem público legalmente verificado exigir o uso, e emprego da Propriedade do Cidadão, será ele previamente indenizado do valor dela. A Lei marcará os casos, em que terá lugar estaúnicaexceção, e dará as regras para se determinar a indemnização (BRASIL,1824).

O direito de propriedade mantem-se em toda a sua plenitude, salvo a desapropriação por necessidade, ou utilidade pública, mediante indemnização prévia (BRASIL, 1891).

É garantido o direito de propriedade, que não poderá ser exercido contra o interesse social ou coletivo, na forma que a lei determinar. A desapropriação por necessidade ou utilidade pública far-se-á nos termos da lei, mediante prévia e justa indenização. Em caso de perigo iminente, como guerra ou comoção intestina, poderão as autoridades competentes usar da propriedade particular até onde o bem público o exija, ressalvado o direito à indenização ulterior (BRASIL, 1934).

O direito de propriedade, salvo a desapropriação por necessidade ou utilidade pública, mediante indenização prévia, ou a hipótese prevista no parágrafo $2^{\circ}$ do artigo 166 (BRASIL,1937).

Neste panorama tem-se ainda a visão clássica do Direito de Propriedade como um bem a ser utilizado. Na Constituição de 1946, passou-se a evidenciar o surgimento de preocupação com o modo de utilização da propriedade, passando o legislador constitucional a

Revista Brasileira de Direito Civil em Perspectiva | e-ISSN: 2526-0243| Porto Alegre | v. 4 | n. 2 |

p. $120-135 \mid$ Jul/Dez. 2018 
vê-la não só como uma propriedade individual por si, mas também como um bem que deve servir de forma mais coletiva. Assim, referido diploma garantia o direito de propriedade, mas, condicionava, com fulcro à ordem econômica, o exercício deste direito ao bem-estar social:

\begin{abstract}
Art. 145. A ordem econômica deve ser organizada conforme os princípios da justiça social, conciliando a liberdade de iniciativa com a valorização do trabalho humano.

Parágrafo único. A todos é assegurado trabalho que possibilite existência digna. O trabalho é obrigação social.

Art. 146. A União poderá, mediante lei especial, intervir no domínio econômico e monopolizar determinada indústria ou atividade. A intervenção terá por base o interesse público e por limite os direitos fundamentais assegurados nesta Constituição.

Art. 147. O uso da propriedade será condicionado ao bem-estar social. A lei poderá, com observância do disposto no art. 141, § 16, promover a justa distribuição da propriedade, com igual oportunidade para todos. "O uso da propriedade será condicionado ao bem-estar social.”(BRASIL,1946).
\end{abstract}

Evidencia-se, nesta oportunidade, uma mudança na visão do legislador, deixando de lado a visão individualista da propriedade e passando a vê-la como peça dentro de algo maior, podendo-se entender esta ponderação como o surgimento embrionário do que viria a ser a Função Social da Propriedade.

A Constituição de 1967 solidifica esta preocupação em seu art. 157 ao definir que a ordem econômica tem por fim, dentre outas questões, garantir a função social da propriedade, preocupação replicada na Constituição Cidadã de 1988 que insere em diversas oportunidades nas quais trata da propriedade a imperatividade de que esta deve atender à sua função social.

Com a evolução do conceito de propriedade, bem como sua interpretação sob a luz dos princípios constitucionais, temos que esta definição consistirá no direito de usar, gozar e dispor do bem, respeitando os interesses sociais e levando a execução deste direito à máxima extensão no sentindo de garantir ao exercício do direito de propriedade a extração máxima da sua função social, de forma a servir não somente ao proprietário, mas à sociedade como um todo, conforme ilustra Lilian Regina Pires:

Impende, portanto, considerar que a função social da propriedade não pode ser confundida com as limitações impostas à propriedade. As limitações estão atreladas a obrigações de fazer ou não-fazer e tais atos são condicionantes para o exercício do direito. Já a função social se constitui em um dever que objetiva a manutenção da proteção do seu direito. (PIRES, 2007)

Revista Brasileira de Direito Civil em Perspectiva | e-ISSN: 2526-0243| Porto Alegre | v. 4 | n. 2 |

p. $120-135$ | Jul/Dez. 2018 
Passa-se a identificar, pois, uma visão nova do próprio conceito de propriedade que deixa-se de vincular tão-somente ao detentor dos seus direitos e transmuta-se a uma visão de um panorama que insere a propriedade como meio de concretização de direitos sociais.

É sobre esta nova roupagem da propriedade, direcionada pelo princípio constitucional da função social que surgem novos modelos de um bem já tutelado, qual seja, a propriedade.

\section{A MULTIPROPRIEDADE IMOBILIÁRIA COMO DIREITO REAL À LUZ DA CONSTITUCIONALIZAÇÃO DO DIREITO CIVIL}

A evolução das relações jurídicas entre os membros da sociedade faz necessária uma evolução dos conceitos, institutos e normas legais. Assim, a relação do homem com a propriedade também evoluiu, fazendo necessária a evolução dos regramentos aplicáveis a este instituto.

Costumeiramente, em especial nas regiões turísticas, são adquiridos imóveis com o objetivo não residencial, mas de utilização por períodos específicos durante o ano. A subutilização periódica desses imóveis traz consigo uma série de consequências negativas, dentre as quais o custo-benefício não convidativo e a majoração da insegurança em detrimento de uma determinada cidade costeira, por exemplo, ter uma série de imóveis não habitados por uma grande parte do ano.

Nos anos de 1960, na Europa, com mais concentração entre os países de vocação turística, iniciou-se uma tendência no fracionamento da propriedade não só em frações ideais de terrenos, como nos condomínios edilícios e horizontais, mas através de frações de tempo da integralidade do bem, o que hoje denomina-se Multipropriedade Imobiliária.

Com origem na Itália, atualmente, já difundida em diversos países, a multipropriedade imobiliária tem avançado a passos largos no Brasil nos últimos anos. Os altos custos trabalhistas e tributários nacionais, dentre outras questões, tornaram deveras onerosa a manutenção de casas de veraneio, fazendo com que o mercado imobiliário brasileiro, ligado à ideia da manutenção deste costume de ter a segunda casa, buscasse no direito alienígena alternativas mais baratas.

Revista Brasileira de Direito Civil em Perspectiva | e-ISSN: 2526-0243| Porto Alegre | v. 4 | n. 2 |

p. $120-135$ | Jul/Dez. 2018 
A multipropriedade surgiu como opção para driblar estes altos custos bem como evitar a subutilização da propriedade. Mediante o sistema de time-sharing uma diversidade de coproprietários de um determinado imóvel pode dividir os custos de manutenção daquele e utilizá-lo por um período específico.

Carente de regulamentação legal, identificamos na multipropriedade imobiliária um bem jurídico necessitado de regulamentação jurídica, como ensina Perlingieri:

As coisas corpóreas - em si abstratamente úteis ao homem - são sempre bens jurídicos mesmo quando não sejam objeto atual de direitos, já que são sempre bens jurídicos mesmo quanto não sejam objeto atual de direitos, já que são sempre idôneas para sê-lo (PERLINGIERI, 2007).

Evidenciando-se na multipropriedade imobiliária um bem jurídico ainda não regulado, o mercado imobiliário buscou opções e nem sempre adequadas de trazer regramentos a esta nova relação que surgia com o escopo de dar-lhe segurança jurídica, como afirma Gustavo Tepedino:

Do ponto de vista da indústria turístico-hoteleira e de serviços, a economia das regiões envolvidas torna-se aquecida em todos os períodos do ano, e não apenas nas altas estações. Estimulam-se o desenvolvimento e a estabilidade do comércio local de maneira contínua, favorecendo, ainda, o equilíbrio econômico, na medida em que resguarda o meio ambiente contra a proliferação indiscriminada de construções. Com o desenvolvimento da multipropriedade, diversos mercados imobiliários conseguiram superar a crise recessiva em que se encontravam, tornando-se o novo sistema objeto de estudos e debates em numerosos países. No Brasil, empreendimentos do gênero receberam boa aceitação no Rio de Janeiro, Rio Grande do Sul e São Paulo, posto que inibidos por alguma dose de incerteza acerca dos direitos e prerrogativas do titular.

Tendo a autonomia privada se antecipado ao legislador, números modelos jurídicos foram desenhados para regulamentar a operação, designada como multipropriedade; time-sharing; droit de jouissance à tempspartagé; proprietéspatio-temporelle; multijouissance; multiproprietá; direito real de habitação periódica(TEPEDINO, 2017).

Nesta modalidade de alienação, o comprador adquire uma fração do imóvel, fazendo jus a utilizá-lo com exclusividade e animus de dono durante determinado período especifico, comumente fracionado no interregno de um ano, denominando-se multiproprietário.

Com o surgimento deste novo instituto, uma parcela da sociedade que antes via na "casa de praia" ou "casa de veraneio" um sonho intangível, passou a ter acesso a este "luxo"

Revista Brasileira de Direito Civil em Perspectiva | e-ISSN: 2526-0243| Porto Alegre | v. 4 | n. 2

p. $120-135$ | Jul/Dez. 2018 
pagando apenas pela fração de tempo durante o qual desejava ser propriedade e, portanto, uma fração do valor do imóvel e dos seus custos de manutenção, apesar de beneficiar-se no período em que especificamente desejava.

Assim, identifica-se na multipropriedade imobiliária uma espécie da qual o condomínio é gênero. Utilizada, como dito, costumeiramente em locais de lazer, esta terá o condão de dividir o aproveitamento econômico do imóvel entre os cotitulares fixando sua utilização por períodos pré-definidos e assegurando o uso exclusivo e perpétuo naqueles momentos.

Em detrimento do princípio numerus clausus, previsto no Código Civil Brasileiro, que sustenta o dogma da taxatividade dos direitos reais, bem como do reforço a esta ideia trazida pelo art. 172 da Lei 6.105/73, durante muito tempo, muitos defendiam a figura da multipropriedade como uma faceta do direito obrigacional, e não como direito real, visão, que se acredita ser inapropriada.

A multipropriedade encontra características inerentes e indissociáveis ao instituto da propriedade, em especial o animus do comprador, quem, ao adquirir fração imobiliária por meio de time-sharing ou multipropriedade imobiliária, não objetiva o mero direito de uso, ou mesmo posse temporária do bem, mas efetivo direito de usar, gozar e dispor do bem, de forma exclusiva e definitiva, equiparando-se ao tradicional direito à propriedade historicamente chancelado pelo Direito Civil.

A despeito da taxatividade esculpida no princípio numerus clausus utilizada por alguns como argumento para reduzir a multipropriedade a uma relação de natureza obrigacional, entende-se, a uma, que, em respeito à autonomia da vontade, não deseja o multiproprietário assumir uma obrigação perante um terceiro, mas efetivamente obter relação com um bem. Tem-se, portanto, na multipropriedade, um Direito ius in re, e não jus ad rem, como nas relações obrigacionais:

[...] com o termo multipropriedade designa-se, genericamente, a relação jurídica de aproveitamento econômico de uma coisa móvel ou imóvel, repartida em unidades fixas de tempo, de modo que diversos titulares possam, cada qual a seu turno, utilizar-se da coisa com exclusividade e de forma perpétua. (TEPEDINO, 2017).

Na mesma linha, Dario da Silva Oliveira Junior e Victor Emanuel Christofari conceituam a multipropriedade imobiliária como sendo:

Revista Brasileira de Direito Civil em Perspectiva | e-ISSN: 2526-0243| Porto Alegre | v. 4 | n. 2 |

p. $120-135$ | Jul/Dez. 2018 
Relação jurídica de aproveitamento econômico de uma coisa móvel ou imóvel, coisa essa repartida em unidades fixas de tempo, de modo a permitir que diversos titulares possam utilizar-se daquela coisa com exclusividade, cada um a seu turno, de maneira perpétua ou não". (CHRISTOFARI JUNIOR; EMANUEL, 2000)

Da conceituação trazida pela doutrina, percebem-se que a discussão da multipropriedade como Direito Real não advém da sua conceituação ou da vontade dos sujeitos ativos no exercício do Direito de Multipropriedade, mas é consequência da restrição civilista quem, ao instituir o princípio numerus clausus, impôs, no art. 1.225 do Código Civil Brasileiro uma taxatividade que trouxe como direitos reais.

Não demanda grandes esforços para entender que, com os avanços tecnológicos e a globalização, características do século XXI, qualquer diploma legal que tenha a pretensão de codificar taxativamente as modalidades de negócios e direitos reais a serem tutelado, fracassará nessa empreitada e, consequentemente, trará consigo uma legião de negócios e bens jurídicos, naturalmente, surgidos pelas relações interpessoais que ficarão às margens de uma legislação específica regulamentadora.

Ante esta realidade, faz-se imprescindível a interpretação do Direito Civil, em especial do art. 1225 desta legislação sob a orientação da Função Social, para que a propriedade, seja ela de proprietários unitários ou múltiplos, cumpra seu destino economicamente útil em sua máxima produtividade, conforme leciona Oliveira (2006):

[...] consiste em que a propriedade deve cumprir um destino economicamente útil, produtivo, de maneira a satisfazer as necessidades sociais preenchíveis pela espécie tipológica do bem, cumprindo sua vocação natural, de modo a canalizar as potencialidades residentes no bem em proveito da coletividade ou pelo menos, não poderá ser utilizada de modo a adversá-las.

Assim, deve o instituto da multipropriedade imobiliária ser encarado como faceta da propriedade conforme é previsto no Art. 1225 do Código Civil Brasileiro, o qual, em respeito ao princípio da Função Social da Propriedade confere plenitude de utilização econômica, trazendo a possibilidade do Direito de Multipropriedade ser exercido com a máxima produtividade e maior retorno possível à sociedade que circunda o bem imóvel.

Revista Brasileira de Direito Civil em Perspectiva | e-ISSN: 2526-0243| Porto Alegre | v. 4 | n. 2 |

p. $120-135$ | Jul/Dez. 2018 


\section{A REGULAMENTAÇÃO DA MULTIPROPRIEDADE IMOBILIÁRIA NO DIREITO BRASILEIRO}

Conforme apresentado nas linhas anteriores, entende-se que a Multipropriedade Imobiliária, inobstante a defesa da taxatividade do art. 1.225, não é vedada pelo Código Civil de 2002, uma vez que nada mais é do que uma modalidade de condomínio na ascensão mais pura da palavra, e, portanto, trata-se da propriedade, já tutelada como direito real.

O Código Civil (BRASIL, 2002), em seu art. 1.315, estabelece que "o condômino é obrigado, na proporção de sua parte, a concorrer para as despesas de conservação ou divisão da coisa e a suportar os ônus a que estiver sujeita."

A multipropriedade imobiliária, e por consequência o multiproprietário, nada mais intenta que utilizar, gozar e dispor da proporção do bem, no nosso estudo, imóvel adquirido, arcando, por conseguintes, com seus ônus de responsabilidade, tributação e etc, inerentes à "unipropriedade imobiliária"

Ao ser enfrentada pelo Superior Tribunal de Justiça (STJ), a situação gerou, em um primeiro momento, decisões não unânimes, por meio das quais se discutiu a taxatividade dos direitos reais, ou seja, ventilou-se se estes seriam tão somente os positivados na legislação civil, ou se o Código Civil Brasileiro abriria a possibilidade evolutiva de novos direitos reais à medida em que as relações patrimoniais evoluíssem.

Segundo a Decisão proferida no Resp 1546165 / SP, de Relatoria do Ministro Ricardo Vilas BôasCuevas, entendeu o Superior Tribunal de Justiça, por maioria, que o Código Civil de 2002, assim como a legislação civilista anterior, não prevê vedação à consagração de novos Direitos Reais, bem como que as características específicas da Multipropriedade Imobiliária encontram-se em harmonia com os Direitos Reais, em especial por trazerem a viabilidade da utilização do bem em sua plenitude, mediante o compartilhamento pelos multiproprietários, de espaço e turnos fixos de tempo (BRASIL, 2006):

PROCESSUAL CIVIL E CIVIL. RECURSO ESPECIAL. EMBARGOS DE TERCEIRO.MULTIPROPRIEDADE IMOBILIÁRIA (TIMESHARING). NATUREZA JURÍDICA DEDIREITO REAL. UNIDADES FIXAS DE TEMPO. USO EXCLUSIVO E PERPÉTUODURANTE CERTO PERÍODO ANUAL. PARTE IDEAL DO MULTIPROPRIETÁRIO. 


\section{PENHORA. INSUBSISTÊNCIA. RECURSO ESPECIAL CONHECIDO E PROVIDO.}

1. O sistema time-sharing ou multipropriedade imobiliária, conforme ensina Gustavo Tepedino, é uma espécie de condomínio relativo alocais de lazer no qual se divide o aproveitamento econômico de bemimóvel (casa, chalé, apartamento) entre os cotitulares em unidades fixas de tempo, assegurandose a cada um o uso exclusivo e perpétuodurante certo período do ano.

2. Extremamente acobertada por princípios que encerram os direitos reais, a multipropriedade imobiliária, nada obstante ter feição obrigacional aferida por muitos, detém forte liame com o institutoda propriedade, se não for sua própria expressão, como já vemproclamando a doutrina contemporânea, inclusive num contexto de nãose reprimir a autonomia da vontade nem a liberdade contratual dianteda preponderância da tipicidade dos direitos reais e do sistema de numerus clausus.

3. No contexto do Código Civil de 2002, não há óbice a se dotar o instituto da multipropriedade imobiliária de caráter real,especialmente sob a ótica da taxatividade e imutabilidade dosdireitos reais inscritos no art. 1.225 .

4. O vigente diploma, seguindo os ditames do estatuto civilanterior, não traz nenhuma vedação nem faz referência àinviabilidade de consagrar novos direitos reais. Além disso, com osatributos dos direitos reais se harmoniza o novel instituto, que,circunscrito a um vínculo jurídico de aproveitamento econômico e deimediata aderência ao imóvel, detém as faculdades de uso, gozo edisposição sobre fração ideal do bem, ainda que objeto de compartilhamento pelos multiproprietários de espaço e turnos fixosde tempo.

5. A multipropriedade imobiliária, mesmo não efetivamente codificada, possui natureza jurídica de direito real,harmonizando-se, portanto, com os institutos constantes do rolprevisto no art. 1.225 do Código Civil; e o multiproprietário, no caso de penhora do imóvel objeto de compartilhamento espaço-temporal(time-sharing), tem, nos embargos de terceiro, o instrumentojudicial protetivo de sua fração ideal do bem objeto de constrição.

6. É insubsistente a penhora sobre a integralidade do imóvelsubmetido ao regime de multipropriedade na hipótese em que a parteembargante é titular de fração ideal por conta de cessão de direitosem que figurou como cessionária.

7. Recurso especial conhecido e provido.

Consolidou, portanto, o STJ entendimento não só da característica de Direito Real à multipropriedade imobiliária, mas que, mesmo não estando codificada, seria possível ao multiproprietário opor embargos de terceiro contra decisão que determinou a penhora da integralidade do bem de cuja multipropriedade lhe pertence, declarando insubsistente a penhora sobre a integralidade do imóvel submetido ao regime de multipropriedade pelo fato e reconhecer o Direito Real de Multipropriedade ao embargante. 
Já aceita pelo Judiciário e amplamente difundida no mercado imobiliário, a Multipropriedade Imobiliária, em virtude da falta de regulamentação legal, mesmo reconhecida como Direito Real vem sendo encarada como "negócio atípico", uma vez que paira sobre a M Multipropriedade Imobiliária insegurança jurídica quanto à organização da copropriedade e limitação das responsabilidades tributárias sobre o imóvel.

Assim, evidencia-se dificuldade em entender qualquer resistência à aceitação da Multipropropriedade Imobiliária como Direito Real, essa, nada mais é que uma modalidade de propriedade, já inserida no art. 1.1225, no inciso I, bastando simples aplicação de hermenêutica interpretativa para inferir-se tal realidade, como leciona Gustavo Tepedino:

\begin{abstract}
Não há qualquer restrição, portanto, no texto legal, para que se institua o condomínio edilício mediante a discriminação e individualização espaçotemporal de unidades autônomas de propriedade exclusiva. Diante das novas formas de utilização dos bens, deve o intérprete procurar desenvolver critérios hermenêuticos que possam compatibilizar a função à qual se destina o bem com a estrutura normativa disponível, renovando-se a cada dia a letra da lei, reelaborando-a diante do dado social e criando, assim, critérios de avaliação de negócios em geral, em particular os novos negócios, de tal modo a promover de modo adequado a atividade econômica pretendida. (TEPEDINO, 2017).
\end{abstract}

Carecendo, portanto, tão somente de regulamentação quanto à organização do exercício da copropriedade e a responsabilidade pelos ônus a ela inerentes.

Igualmente, o Direito Real de Laje, já estava tutelado no Código Civil, no inciso I do art. 1.225, uma vez que configura-se um efetivo direito de propriedade, no qual o proprietário intenta usar, gozar e dispor, como prevê o artigo. 1228 do Código Civil, da laje. Assim, como à multipropriedade imobiliária, o que carecia ao Direito de Laje era tão somente a regulamentação da sua utilização, trazida pelo art. 1.510 do Código Civil.

A inserção do inciso XIII, por meio da Medida Provisória 759, portanto, confundiu uma modalidade de propriedade como se outro direito fosse e engessou futuras modalidades de propriedades que venham a existir, deixando-as reféns da necessidade da criação de novos incisos no art. 1.225 do Código Civil de 2002 para que possam ser vistas como direitos reais.

A tramitação no Congresso Nacional processo de aprovação do Projeto de Lei 54/2017, já aprovado pela Comissão de Constituição, Justiça e Cidadania promete trazer o mesmo tratamento à multipropriedade imobiliária, trazendo novo inciso ao art. 1.225 do

Revista Brasileira de Direito Civil em Perspectiva | e-ISSN: 2526-0243| Porto Alegre | v. 4 | n. 2 |

p. $120-135 \mid$ Jul/Dez. 2018 
Código Civil para prever a multipropriedade imobiliária como se algo diverso da propriedade o fosse.

A simples inserção de artigo no Código Civil para regulamentar a funcionalidade da copropriedade e as limitações dos ônus do imóvel e obrigações inerentes a eles seriam suficientes para o regramento do instituto.

Aprovado referido projeto se tem, tão-somente a formalização de realidade fática amplamente aplicada em diversas cidades do País, temos, portanto, a confirmação legislativa da natureza jurídica de Direito Real à Multipropriedade Imobiliária já ostentada enquanto simples propriedade codividida no tempo.

\section{CONCLUSÃO}

Os estudos sobre multipropriedade imobiliária têm enorme importância no panorama jurídico do país, uma vez que mesmo já estando o conceito e formatação jurídica deste instituto amplamente aplicado nacional e internacionalmente, bem como sendo a discussão já aceita pelos tribunais pátrios, por falta de estudo aprofundado, deixa muitas dúvidas aos operadores do direito, causando ainda hoje equívocos de conceituação e tratamento.

Durante muito tempo ignorou-se a existência da multipropriedade imobiliária, sendo por muitos doutrinadores considerado mera relação obrigacional. Os que argumentam contra a visão da multipropriedade como direito real sustentam-se na ideia da taxatividade oriunda do princípio numerus clausus do Código Civil Brasileiro.

Esta argumentação apresenta uma grande impropriedade teórica no que tange ao conceito do instituto objeto do presente estudo, uma vez que este não passa de uma modalidade de propriedade, este previsto no inciso I do art. 1.225 do Código Civil e, portanto, não só tutelado pela legislação civilista como banhado na proteção de direito real.

Apesar da existência de certa resistência à aceitação deste conceito, a maior parte da doutrina e jurisprudência brasileiras já acatam a visão da multipropriedade como Direito Real, visão esta, inclusive, chancelada pelo Superior Tribunal de Justiça.

O Código Civil brasileiro, em seu artigo 1.225 preceitua serem direitos reais, dentre outros, a propriedade. Sendo clara a inexistência de vedação legal para a aplicação da teoria estudada, ao contrário, encontra esta embasamento no ordenamento jurídico brasileiro em

Revista Brasileira de Direito Civil em Perspectiva | e-ISSN: 2526-0243| Porto Alegre | v. 4 | n. 2 |

p. $120-135$ | Jul/Dez. 2018 
especial ante à interpretação da norma civilista à luz da Função Social da propriedade, trazendo à propriedade subutilizada, com a roupagem de multipropriedade, a possibilidade da sua plena exploração econômica e produtiva.

Demonstrou-se nas linhas anteriores no que consiste a multipropriedade imobiliária, abordando-se o seu surgimento no direito europeu, as suas principais características, e objetivos, tais como o de utilização plena de bem imóvel pelo multiproprietário. Fez-se uma análise histórico-evolutiva dessa teoria, fazendo-se uma abordagem desde o seu surgimento na Itália, passando-se pelas suas diversas roupagens jurídicas até que se chegasse à regulamentação desta no direito brasileiro.

Averiguou-se o conceito da multipropriedade imobiliária conceituando-a como um modelo de propriedade. Classificou-se esta como uma forma de exploração da propriedade em sua plenitude com o escopo de alcançar em grau máximo a função social da propriedade.

Salientou-se a importância da correta conceituação desta modalidade de propriedade, bem como da necessidade do enquadramento correto deste instituo pelo Congresso Nacional para que a regulamentação pela via equivocada do mesmo não tenha por consequência um engessamento dos Direitos Reais, mas uma evolução no conceito de propriedade à luz da constitucionalização do direito civil.

Assevera-se, finalmente, que, embora diversos julgados já sejam fundamentados com base no conceito aqui trazido de multipropriedade imobiliária, a doutrina, a despeito de invocarem o mesmo conceito, defende uma regulamentação do instituto de forma que trará prejuízo a futuras modalidades de propriedade.

Entende-se que a técnica adequada para regulamentação deste instituto seria enxergálo como um tipo de propriedade e, portanto, já protegido pelas garantias inerentes ao direito real, uma vez que consignados, enquanto propriedade, no inciso I do art. 1.225 do Código Civil

Assim, conclui-se que a melhor maneira de regulamentação da multipropriedade seria enquadrá-la como propriedade e inserir no código civil capítulo específico que viria, tão somente, a regimentar como dar-se-ia a execução do direito real a multipropriedade e a limitação de responsabilidades do multiproprietário.

\section{REFERÊNCIAS}

Revista Brasileira de Direito Civil em Perspectiva | e-ISSN: 2526-0243| Porto Alegre | v. 4 | n. 2 |

p. $120-135 \mid$ Jul/Dez. 2018 
BRASIL. Constituição (1988) Constituição da República Federativa do Brasil. Texto constitucional promulgado em 5 de outubro de 1988. Brasília, DF, Senado, 1998. Disponível em: <http://www.planalto.gov.br/ccivil_03/constituicao/constituicaocompilado.htm>. Acesso em: 04 nov. 2018.

BRASIL. Constituição da República dos Estados Unidos do Brasil, de 24 de fevereiro de 1891. Nós, os representantes do povo brasileiro, reunidos em Congresso Constituinte, para organizar um regime livre e democrático, estabelecemos, decretamos e promulgamos a seguinte. Disponível em:

<http://www.planalto.gov.br/ccivil_03/constituicao/constituicao91.htm>. Acesso em: 25 abr. 2018.

BRASIL. Constituição da República dos Estados Unidos do Brasil, de 16 de julho de 1934. Nós, os representantes do povo brasileiro, pondo a nossa confiança em Deus, reunidos em Assembléia Nacional Constituinte para organizar um regime democrático, que assegure à Nação a unidade, a liberdade, a justiça e o bem-estar social e econômico, decretamos e promulgamos a seguinte. Rio de Janeiro, RJ, 16 jul. 1934. Disponível em:

<http://www.planalto.gov.br/ccivil_03/constituicao/constituicao34.htm>. Acesso em: 25 abr. 2018.

BRASIL. Constituição da República dos Estados Unidos do Brasil, de 10 de novembro de 1937. Leis Constitucionais. Rio de Janeiro, RJ, 10 nov. 1937. Disponível em:

<www.planalto.gov.br/ccivil_03/constituicao/constituicao37.htm>. Acesso em: 25 abr. 2018. BRASIL. Constituição da República Federativa do Brasil, 24 de janeiro de 1967. Rio de Janeiro, RJ, 18 set. 1967. Disponível em:

<http://www.planalto.gov.br/ccivil_03/constituicao/constituicao67.htm>. Acesso em: 25 abr. 2018 .

BRASIL. Constituição dos Estados Unidos do Brasil, 18 de setembro de 1946. Rio de Janeiro, RJ, 18 set. 1946. Disponível em:

<www.planalto.gov.br/ccivil_03/constituicao/constituicao46.htm>. Acesso em: 25 abr. 2018.

BRASIL. Constituição Política do Império do Brazil, de 25 de março de 1824. Manda observar a Constituição Politica do Imperio, offerecida e jurada por Sua Magestade oImperador. Registrada na Secretaria de Estado dos Negocios do Imperio do Brazil a fls. 17 do Liv. $4^{\circ}$ de Leis, Alvarás e Cartas Imperiaes. Rio de Janeiro, RJ, 22 abr. 1824. Disponível em: <http://www.planalto.gov.br/ccivil_03/constituicao/constituicao24.htm>. Acesso em: 21 jun. 2018.

BRASIL. Lei n. 10.406, de 10 de janeiro de 2002. Institui o CódigoCivil. Diário Oficial [da] República Federativa do Brasil,Brasília, DF, 10 jan. 2002. Disponível em:

<http://www.planalto.gov.br/ccivil_03/leis/2002/110406.htm>. Acesso em: 25 abr. 2018.

BRASIL. Superior Tribunal de Justiça. Recurso Especial n. ${ }^{\circ}$ 788459/BA. Relator: Ministro Fernando Gonçalves. DJ: 13 mar. 2006. Disponível em:

Revista Brasileira de Direito Civil em Perspectiva | e-ISSN: 2526-0243| Porto Alegre | v. 4 | n. 2 |

p. $120-135$ | Jul/Dez. 2018 
<https://stj.jusbrasil.com.br/jurisprudencia/7173792/recurso-especial-resp-788459-ba-20050172410-9/inteiro-teor-12902297>. Acesso em: 21 jun. 2018.

COULANGES, F. D. A cidade antiga. São Paulo: Editora das Américas S.A., 2006.

OLIVEIRA, R. N. A propriedade no Estado Contemporâneo e as relações transnacionais. 2006. 165 fl. Dissertação - Universidade do Vale do Itajaí. Santa Catarina, 2006. Disponível em: <http://siaibib01.univali.br/pdf/Rubia\%20Nazari\%20Oliveira.pdf>. Acesso em: 25 abr. 2018 .

PERLINGIERI, P. Perfis de Direito Civil: Introdução ao Direito Civil Constitucional. Rio de Janeiro: Renovar, 2007.

PIRES, L. R. G. M. Função social da propriedade urbana e o plano diretor. Belo Horizonte: Fórum, 2007.

TEPEDINO, G. Aspectos Atuais da Multipropriedade Imobiliária. In: AZEVEDO, Fábio de Oliveira e MELO, Marco Aurélio Bezerra de (Org.). Direito Imobiliário. São Paulo: Atlas, 2015, p. 512-522. Disponível em: <http://www.tepedino.adv.br/wpp/wpcontent/uploads/2017/07/Aspectos_Atuais_Multipropriedade_imobiliaria_fls_512-522.pdf> Acesso em: 21 jun. 2018 